Benny Karuniawati, Berlina Putrianti "'Gambaran Perilaku Hidup Bersih dan Sehat (PHBS) dalam Pencegahan Penularan Covid-19" (hal 112-131)

Received

06 Juni 2020
Revisied

28 Juli 2020
Acceptep

15 Oktober 2020

\title{
GAMBARAN PERILAKU HIDUP BERSIH DAN SEHAT (PHBS) DALAM PENCEGAHAN PENULARAN COVID-19
}

\author{
Benny Karuniawati ${ }^{1}$, Berlina Putrianti ${ }^{2}$ \\ ${ }^{1}$ Prodi D III Kebidanan, Poltekkes Karya Husada Yogyakarta \\ $1_{\text {email: bennykaruniawati@gmail.com }}$ \\ ${ }^{2}$ Prodi D III Kebidanan, Poltekkes Karya Husada Yogyakarta \\ 2 email: putriberlina@gmail.com
}

\section{ABSTRAK}

PHBS adalah upaya secara sadar, mau dan mampu memelihara dan meningkatkan kesehatannya, mencegah resiko terjadinya penyakit dan melindungi diri dari ancaman penyakit serta berperan aktif dalam gerakan kesehatan. Penelitian ini bertujuan untuk mendapatkan gambaran pelaksanaan PHBS masyarakat dalam upaya pencegahan penularan virus Covid 19. Jumlah sampel dalam penelitian sebanyak 71 responden dengan total 19 item pertanyaan. Data penelitian ini diambil dari bulan Februari sampai dengan bulan Juni 2020. Hasil penelitian menunjukkan bahwa dari 71 responden terdapat 83,1\% selalu mencuci tangan setelah keluar rumah, 76,1\% selalu mencuci tangan sebelum makan, $67,5 \%$ membersihkan rumah, 95,8\% menggunakan masker, terdapat $47,9 \%$ sering menjaga jarak aman saat diluar rumah minimal 2 meter, 63,4\% tidak berjabat tangan, 22,5\% masih aktif menghadiri kegiatan diluar rumah, 80,3\% selalu membuka jendela dan ventilasi, $45,1 \%$ membersihkan benda yang ada dirumah dengan cairan pembersih setiap hari, $71,8 \%$ selalu menyediakan makanan sehat untuk keluarga, 32,4\% yang selalu dan sering merokok dimasa pandemik, $43,7 \%$ berolahraga minimal 30 menit setiap hari, 54,9\% menyiapkan makan cepat saji untuk keluarga, 95,8\% mencuci buah dan sayur sebeleum dikonsumsi, 49,3\% mencuci tangan setelah memegang uang, 77,5\% selalu membiasaan seluruh keluarga untuk hidup sehat, 78,9\% mengkonsumsi minimal 2liter cairan dalam sehari, dan $84,5 \%$ tidak pernah melakukan perjalanan keluar kota.

Kata kunci: PHBS, covid-19

\section{ABSTRACT}

PHBS is a conscious effort, willing and able to maintain and improve their health, prevent the risk of disease and protect themselves from disease threats and play an active role in the health movement. This study aims to obtain an overview of the implementation of community PHBS in an effort to prevent the transmission of the Covid 19 virus. The number of samples in the study were 71 respondents with a total of 19 question items. The research data was taken from February to June 2020. The results showed that out of 71 respondents, $83.1 \%$ always washed their hands after leaving the house, $76.1 \%$ always washed their hands before eating,67.5\% cleaned the house, 95 , 8\% use masks, 47.9\% often maintain a safe distance outside the house at least 2 meters, $63.4 \%$ do not shake hands, $22.5 \%$ still actively attend activities outside the home, $80.3 \%$ always open windows and ventilation, $45.1 \%$ cleaned objects at home with cleaning fluid every day, $71.8 \%$ always provided healthy food for the family, 32.4\% always and often smoked during the pandemic, $43.7 \%$ exercised at least 30 minutes every day, $54.9 \%$ prepare fast food for the family, 95.8\% wash fruits and vegetables before consumption, $49.3 \%$ wash their hands after handling money, $77.5 \%$ always habituate the whole family to be healthy, $78.9 \%$ consume the minimum 2liter of fluid a day, and $84.5 \%$ ti never traveled out of town.

Keywords: PHBS, covid-19 
Jurnal Kesehatan Karya Husada, Vol 8 No 2 Tahun 2020

PISSN 2337649X/EISSN 2655-8874

Benny Karuniawati, Berlina Putrianti "'Gambaran Perilaku Hidup Bersih dan Sehat (PHBS) dalam Pencegahan Penularan Covid-19" (hal 112-131)

\section{PENDAHULUAN}

Ancaman terbaru terhadap kesehatan global adalah wabah penyakit pernapasan yang sedang berlangsung yang baru-baru ini diberi nama Coronavirus Disease 2019 (Covid19). Covid-19 mulai muncul pada bulan Desember 2019. Wabah Covid19 telah menimbulkan tantangan penting bagi kesehatan masyarakat, penelitian, dan komunitas medis (WHO, 2020).

Sekitar 115.000 kasus dikonfirmasi penyakit Covid 19 yang disebabkan oleh coronavirus novel 2019 (SARS- CoV-2) telah dilaporkan, termasuk sekitar 5.388 kematian di Indonesia. Pada 11 Maret 2020, Organisasi Kesehatan Dunia menyatakan wabah COVID-19 sebagai pandemi. Data dari China menunjukkan bahwa orang dewasa yang lebih tua, terutama mereka yang memiliki kondisi kesehatan serius, berisiko lebih tinggi untuk penyakit dan kematian terkait COVID-19 yang parah dibandingkan orang yang lebih muda. Meskipun mayoritas kasus COVID-19 yang dilaporkan di Cina adalah ringan (81\%), sekitar 80\% kematian terjadi di antara orang dewasa berusia $\geq 60$ tahun; hanya satu $(0,1 \%)$ kematian terjadi pada seseorang berusia $\leq 19$ tahun (Zou et al.,2020).

Efisiensi penularan virus pernapasan memiliki implikasi penting bagi strategi penahanan dan mitigasi. Studi saat ini menunjukkan perkiraan angka reproduksi dasar (R0) 2,2, yang berarti bahwa, rata-rata, setiap orang yang terinfeksi menyebarkan infeksi ke dua orang tambahan. Seperti yang dicatat oleh penulis, hingga angka ini turun di bawah 1.0, kemungkinan wabah akan terus menyebar. Laporan terbaru tentang titer virus yang tinggi di orofaring pada awal perjalanan penyakit menimbulkan kekhawatiran tentang peningkatan infektivitas selama periode gejala minimal(Holshue et al., 2020; Zou et al., 2020).

Menteri Kesehatan Republik Indonesia membuat Pedoman Pembinaan Perilaku Hidup Bersih dan Sehat yang tertuang dalam Peraturan Menteri Kesehatan Republik Indonesia

Nomor:2269/MENKES/PER/XI/2011 yang mengatur upaya peningkatan perilaku hidup bersih dan sehat atau disingkat PHBS di 
Jurnal Kesehatan Karya Husada, No 8 Vol 2 Tahun 2020

PISSN 2337649X/EISSN 2655-8874

Benny Karuniawati, Berlina Putrianti “" Gambaran Perilaku Hidup Bersih dan Sehat (PHBS) dalam Pencegahan Penularan Covid-19" (hal 112-131)

seluruh Indonesia dengan mengacu kepada pola manajemen PHBS.

Perilaku tersebut diharapkan dapat diterapkan pada semua golongan masyarakat termasuk anak usia sekolah. Banyak faktor yang mempengaruhi perilaku hidup bersih dan sehat seperti kebiasaan dirumah, lingkungan,masyarakat.

Perilaku Hidup Bersih dan Sehat (PHBS) merupakan cerminan pola hidup keluarga yang senantiasa memperhatikan dan menjaga kesehatan seluruh anggota keluarga. Semua perilaku kesehatan yang dilakukan atas kesadaran sehingga anggota keluarga atau keluarga dapat menolong dirinya sendiri dibidang kesehatan dan dapat berperan aktif dalam kegiatan-kegiatan kesehatan di masyarakat merupakan pengertian lain dari PHBS. (Proverawati,2012).

Menurut WHO beberapa perilaku kesehatan yang dapat mengurangi kemungkinan terinfeksi atau menyebarkan COVID-19 dengan melakukan penerapan PHBS diantaranya selalu mencuci tangan, menjaga jarak 1-3 meter, Hindari pergi ke tempat keramaian, Hindari menyentuh mata, hidung dan mulut, Tetap di rumah dan isolasi diri bahkan dengan gejala ringan(WHO, 2019).

Berdasarkan latar belakang tersebut maka peneliti tertarik untuk melihat sejauh mana penerapan PHBS pada masyarakat untuk mengatasi penularan Covid-19.

\section{METODE PENELITIAN}

Penelitian ini dilakukan seluruh Indonesia dengan menggunakan kuesioner yang dapat diakses secara online. Penelitian ini menyajikan data deskriptif dengan menguraikan perilaku masyarakat dalam pencegahan penyebaran Covid-19. Jumlah sampel dalam penelitian sebanyak 71 responden dengan total 19 item pertanyaan. Data penelitian ini diambil dari bulan Februari sampai dengan bulan Juni 2020.

Pengolahan data terdiri dari beberapa tahap, diantaranya editing, koding agar memudahkan dalam pengolahan data. Model analisis data yang dilakukan adalah analisis univariat. Data yang telah dianalisis disajikan dalam bentuk tabel distribusi yang dilengkapi dengan narasi sebagai pelengkap tabel. 
Jurnal Kesehatan Karya Husada, No 8 Vol 2 Tahun 2020

PISSN 2337649X/EISSN 2655-8874

Benny Karuniawati, Berlina Putrianti “"Gambaran Perilaku Hidup Bersih dan Sehat (PHBS) dalam Pencegahan Penularan Covid-19" (hal 112-131)

\section{HASIL DAN PEMBAHASAN}

Berdasarkan hasil pengambilan data yang dilakukan dengan 71 responden diperoleh beberapa data karakteristik meliputi Pendidikan, pekerjaan dan usia. Berikut tabel karakteristik responden.

Tabel 4.1: Karakteristik responden

\begin{tabular}{|c|c|c|c|}
\hline No & Karakteristik & Jml & $\%$ \\
\hline \multirow[t]{4}{*}{1} & Usia & & \\
\hline & - $<20^{\text {th }}$ & 1 & 1,4 \\
\hline & - $20-35^{\text {th }}$ & 37 & 52,1 \\
\hline & - $>35$ th & 33 & 46,5 \\
\hline \multirow[t]{8}{*}{2} & Pendidikan & & \\
\hline & - SMP & 2 & 2,8 \\
\hline & - SMA & 3 & 4,2 \\
\hline & sederajat & & \\
\hline & - Diploma & 20 & 28,2 \\
\hline & - Sarjana & 27 & 38 \\
\hline & - Magister & 8 & 11,4 \\
\hline & - Doktor & 1 & 1,4 \\
\hline \multirow[t]{4}{*}{3} & Pekerjaan & & \\
\hline & $\begin{array}{l}\text { - } \quad \text { Tidak } \\
\text { bekerja }\end{array}$ & 19 & 26,8 \\
\hline & - Swasta & 30 & 42,2 \\
\hline & - PNS & 22 & 31 \\
\hline \multicolumn{2}{|c|}{ Jumlah } & 71 & 100 \\
\hline
\end{tabular}

Berdasarkan tabel karateristik responden dapat disimpulkan bahwa sebagian responden dalam usia reproduksi sehat yaitu rentang 20-35 tahun sebanyak $52,1 \%$, berdasarkan tingkat Pendidikan sebagain besarberpendidikan Sarjana sebanyak $38 \%$ dan pekerjaan swasta sebanyak $42,2 \%$.

Table 4.2 Tabel Distribusi Perilaku Mencuci tangan dengan menggunakan sabun setelah keluar rumah

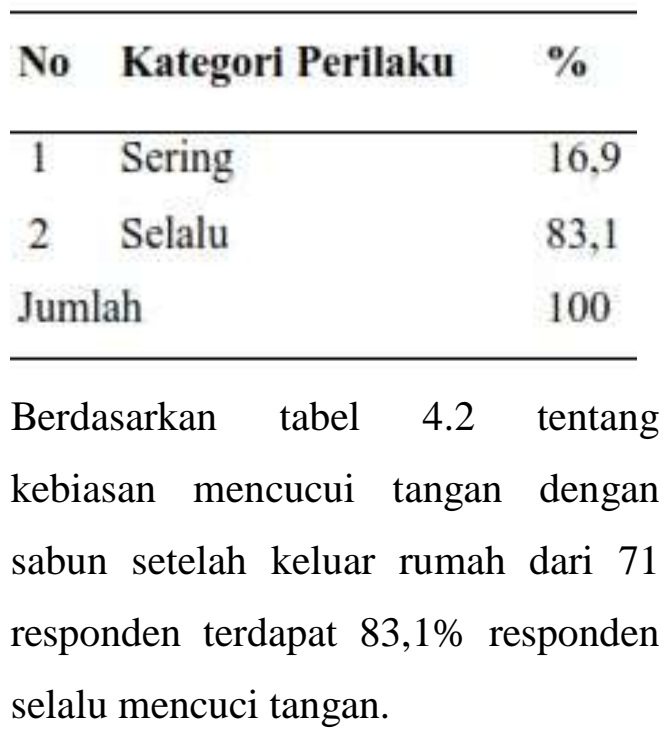

Table 4.3 Tabel Distribusi Perilaku Mencuci tangan dengan menggunakan sabun sebelum makan

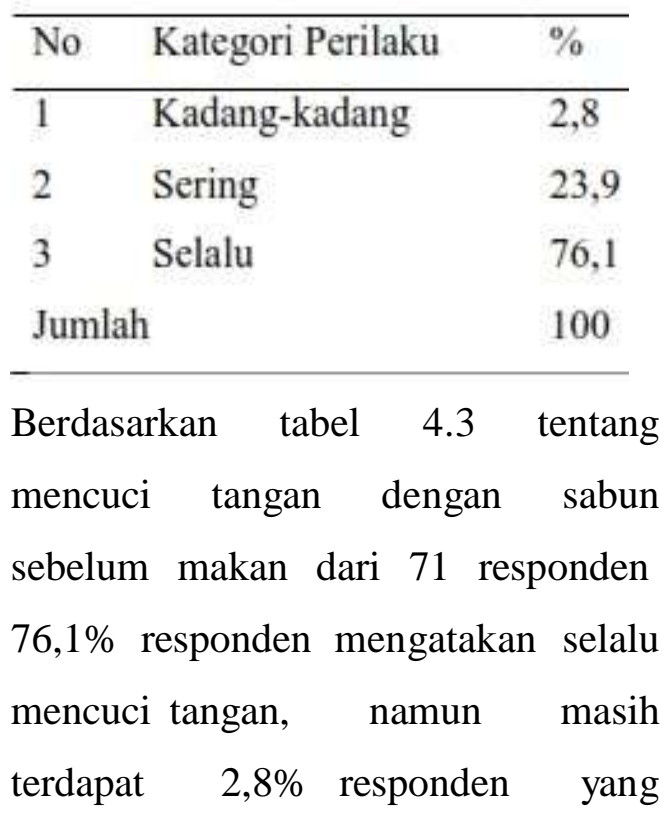


Jurnal Kesehatan Karya Husada, No 8 Vol 2 Tahun 2020

PISSN 2337649X/EISSN 2655-8874

Benny Karuniawati, Berlina Putrianti “"Gambaran Perilaku Hidup Bersih dan Sehat (PHBS) dalam Pencegahan Penularan Covid-19" (hal 112-131)

hanya kadang-kadang saja mencuci tangan sebelum makan.

Table 4.4 Tabel Distribusi

Perilaku Membersihkan rumah setiap hari

\begin{tabular}{cll}
\hline No & Kategori Perilaku & $\%$ \\
\hline 1 & Kadang-kadang & 5,6 \\
2 & Sering & 26,8 \\
3 & Selalu & 67,6 \\
Jumlah & 100
\end{tabular}

Berdasaerkan table 4.4 tentang kebiasaan membersihkan rumah setiap hari dari 71 responden $67,5 \%$ responden menjawab selalu membersihkan rumah setiap hari.

Table 4.5 Tabel Distribusi Perilaku menggunakan masker saat keluar rumah

\begin{tabular}{lll}
\hline No & Kategori Perilaku & $\%$ \\
\hline 1 & Sering & 4,2 \\
2 & Selalu & 95,8 \\
\multicolumn{2}{l}{ Jumlah } & 100 \\
\hline
\end{tabular}

Berdasarkan table 4.5 tentang kebiasaan menggunakan maske saat keluar rumah $95,8 \%$ responden menjawab selalu menggunakan masker.
Table 4.6 Tabel Distribusi Perilaku menjaga jarak aman antar warga minimal 2 meter saat diluar rumah

\begin{tabular}{lll}
\hline No & Kategori Perilaku & $\%$ \\
\hline 1 & Tidak pernah & 1,4 \\
2 & Kadang-kadang & 8,5 \\
3 & Sering & 47,9 \\
4 & Selalu & 42,3 \\
\multicolumn{2}{l}{ Jumlah } & 100 \\
\hline
\end{tabular}

Berdasarkan table 4.6 tentang menjaga jarak aman saat diluar rumah minimal 2 meter terdapat $47,9 \%$ responden mengatakan sering, namun masih terdapat 1,4 responden yang mengabaikan jarak aman 2 meter saat diluar rumah.

Table 4.7 Tabel Distribusi Perilaku berjabat tangan dengan orang lain

\begin{tabular}{lll}
\hline No & Kategori Perilaku & $\%$ \\
\hline 1 & Tidak pernah & 63,4 \\
2 & Kadang-kadang & 23,9 \\
3 & Sering & 7,0 \\
4 & Selalu & 5,6 \\
\multicolumn{2}{l}{ Jumlah } & 100 \\
\hline
\end{tabular}

Berdasarkan table 4.7 tentang kebiasaan berjabat tangan dengan orang lain terdapat $63,4 \%$ sudah tidak berjabat tangan, namun masih terdapat 5,6\% responden yang selalu 
Jurnal Kesehatan Karya Husada, No 8 Vol 2 Tahun 2020

PISSN 2337649X/EISSN 2655-8874

Benny Karuniawati, Berlina Putrianti "'Gambaran Perilaku Hidup Bersih dan Sehat (PHBS) dalam Pencegahan Penularan Covid-19" (hal 112-131)

berjabat tangan di masa pandemic covid 19 saat ini.

Table 4.8 Tabel Distribusi Perilaku aktif melakukan kegiatan diluar rumah

\begin{tabular}{lll}
\hline No & Kategori Perilaku & $\%$ \\
\hline 1 & Tidak pernah & 19,7 \\
2 & Kadang-kadang & 50,7 \\
3 & Sering & 7,0 \\
4 & Selalu & 22,5 \\
Jumlah & 100
\end{tabular}

Berdasarkan table 4.8 tentang aktif melakukan kegiatan diluar rumah masih terdapat $22,5 \%$ yang masih selalu aktif mengahadiri kegiatan diluar rumah.

Table 4.9 Tabel Distribusi Perilaku membuka jendela dan ventilasi dirumah

\begin{tabular}{lll}
\hline No & Kategori Perilaku & $\%$ \\
\hline 1 & Kadang-kadang & 2,8 \\
2 & Sering & 16,9 \\
3 & Selalu & 80,3 \\
Jumlah & & 100
\end{tabular}

Berdasrakan table 4.9 tentang kebiasaan membuka jendela dan ventilasi $80,3 \%$ responden mengatakan selalu, namun masih terdapat $2,8 \%$ yang mengatakan hanya kadang saja membuka jendela maupun ventilasi di rumahnya.

Table 4.10 Tabel Distribusi Perilaku membersihkan permukaan benda yang ada dirumah dengan cairan pembersih setiap hari.

\begin{tabular}{lll}
\hline No & Kategori Perilaku & $\%$ \\
\hline 1 & Tidak pernah & 1,4 \\
2 & Kadang-kadang & 29,6 \\
3 & Sering & 45,1 \\
4 & Selalu & 23,9 \\
Jumlah & & 100 \\
\hline
\end{tabular}

Berdasarkan table 4.10 tentang kebiasaan memberihkan benda yang ada dirumah dengan cairan pembersih setiap hari 45,1 \% responden mengatakan sering, namun masih terdapat $1,4 \%$ responden yang tidak membersihkan permukaan benda dengan cairan pembersih.

Table 4.11 Tabel Distribusi Perilaku menyediakan makanan sehat untuk keluarga. 
Jurnal Kesehatan Karya Husada, No 8 Vol 2 Tahun 2020

PISSN 2337649X/EISSN 2655-8874

Benny Karuniawati, Berlina Putrianti "'Gambaran Perilaku Hidup Bersih dan Sehat (PHBS) dalam Pencegahan Penularan Covid-19" (hal 112-131)

\begin{tabular}{lll}
\hline No & Kategori Perilaku & $\%$ \\
\hline 1 & Kadang-kadang & 2,8 \\
2 & Sering & 25,4 \\
3 & Selalu & 71,8 \\
\multicolumn{2}{l}{ Jumlah } & 100 \\
\hline
\end{tabular}

Berdasarkan table 4.11 tentang kebiasaan menyediakan makanan sehat untuk keluarga $71,8 \%$ responden menjawab selalu.

Table 4.12 Tabel Distribusi Perilaku anggota keluarga yang tetap merokok

\begin{tabular}{lll}
\hline No & Kategori Perilaku & $\%$ \\
\hline 1 & Tidak pernah & 42,3 \\
2 & Kadang-kadang & 25,4 \\
3 & Sering & 15,5 \\
4 & Selalu & 16,9 \\
Jumlah & & 100 \\
\hline
\end{tabular}

Berdasarkan table 4.12 tentang anggota keluarga yang masih merokok dimasa pandemic masih terdapat $32,4 \%$ yang menjawab selalu dan sering.

Table 4.13 Tabel Distribusi Perilaku anggota keluarga rutin berolahraga minimal 30 menit sehari

\begin{tabular}{lll}
\hline No & Kategori Perilaku & $\%$ \\
\hline 1 & Tidak pernah & 8,5 \\
2 & Kadang-kadang & 43,7 \\
3 & Sering & 33,8 \\
4 & Selalu & 14,1 \\
Jumlah & 100 \\
\hline
\end{tabular}

Berdasarkan table 4.13 tentang kebiasaan berolahraga minimal 30 menit setiap hari sebagian besar responden menjawab kadang-kanga yaitu dengan prosentase $43,7 \%$ dan menjawab tidak pernah sebanyak $8,5 \%$.

Table 4.14 Tabel Distribusi Perilaku selalu menyiapkan makanan cepat saji untuk keluarga

\begin{tabular}{lll}
\hline No & Kategori Perilaku & $\%$ \\
\hline 1 & Tidak pernah & 25,4 \\
2 & Kadang-kadang & 54,9 \\
3 & Sering & 11,3 \\
4 & Selalu & 8,5 \\
Jumlah & 100,0 \\
\hline
\end{tabular}

Berdasarkan table 4.14 tentang selalu menyiapkan makan cepat saji untuk keluarga sebagian besar yaitu $54,9 \%$ responden mengatakan kadangkadang. 
Jurnal Kesehatan Karya Husada, No 8 Vol 2 Tahun 2020

PISSN 2337649X/EISSN 2655-8874

Benny Karuniawati, Berlina Putrianti "'Gambaran Perilaku Hidup Bersih dan Sehat (PHBS) dalam Pencegahan Penularan Covid-19" (hal 112-131)

Table 4.15 Tabel Distribusi Perilaku selalu mencuci sayuran dan buah sebelum dikonsumsi keluarga

\begin{tabular}{lll}
\hline No & Kategori Perilaku & $\%$ \\
\hline 1 & Tidak pernah & 0,0 \\
2 & Kadang-kadang & 1,4 \\
3 & Sering & 2,8 \\
4 & Selalu & 95,8 \\
Jumlah & 100,0
\end{tabular}

Berdasarkan table 4.15 tentang kebiasaan mencuci sayuran dan buah sebelum dikonsumsi sebagain besar responden yaitu $95,8 \%$ mengatakanselalu mencuci buah dan sayur sebeleum dikonsumsi.

Table 4.16 Tabel Distribusi Perilaku selalu mencuci tangan setelah memegang uang

\begin{tabular}{lll}
\hline No & Kategori Perilaku & $\%$ \\
\hline 1 & Tidak pernah & 0,0 \\
2 & Kadang-kadang & 12,7 \\
3 & Sering & 38,0 \\
4 & Selalu & 49,3 \\
Jumlah & 100,0
\end{tabular}

Berdasarkan table 4.16 tentang
kebiasaan mencuci tangan setelah
memegang uang sebagian besar
responden yaitu $49,3 \%$ mengatakan

selalu mencuci tangan setelah memegang uang.

Taḅle 4.17 Tabel Distribusi Perilaku membiasakan seluruh keluarga untuk hidup sehat

\begin{tabular}{lll}
\hline No & Kategori Perilaku & $\%$ \\
\hline $1 \quad$ Sering & 22,5 \\
2 & Selalu & 77,5 \\
\multicolumn{2}{l}{ Jumlah } & 100,0 \\
\hline
\end{tabular}

Berdasarkan table 4.17 tentang membiasaan seluruh keluarga untuk hidup sehat $77,5 \%$ responden menjawab selalu.

Table 4.18 Tabel Distribusi Perilaku mengkonsumsi minimal 2 liter cairan dalam sehari

\begin{tabular}{lll}
\hline No & Kategori Perilaku & $\%$ \\
\hline 1 & Tidak pernah & 0,0 \\
2 & Kadang-kadang & 4,2 \\
3 & Sering & 16,9 \\
4 & Selalu & 78,9 \\
Jumlah & 100,0 \\
\hline Berdasarkan table 4.18 & tentang \\
kebiasaan mengkonsumsi & minimal \\
2liter & cairan dalam seharai & sebagian \\
besar & responden yaitu & $78,9 \%$ \\
mengatakan & selalu.
\end{tabular}


Jurnal Kesehatan Karya Husada, No 8 Vol 2 Tahun 2020

PISSN 2337649X/EISSN 2655-8874

Benny Karuniawati, Berlina Putrianti "' Gambaran Perilaku Hidup Bersih dan Sehat (PHBS) dalam Pencegahan Penularan Covid-19" (hal 112-131)

Tabel 4.19 Tabel Distribusi Perilaku keluarga masih aktif melakukan perjalanan ke luar kota

\begin{tabular}{lll}
\hline No & Kategori Perilaku & $\%$ \\
\hline 1 & Tidak pernah & 84,5 \\
2 & Kadang-kadang & 8,5 \\
3 & Sering & 4,2 \\
4 & Selalu & 2,8 \\
Jumlah & 100,0
\end{tabular}

Berdasarkan table 4.19 tentang masih aktifnya anggoita keluarga melakukan perjalan luar kota sebagain besar responden yaitu $84,5 \%$ mengatakan tidak pernah, namun masih terdapat $7 \%$ responden yang melakukan perjalanan keluar kota baik dalam kategori sering maupun selalu.

\section{HASIL DAN PEMBAHASAN}

Hasil analisis data menunjukkan bahwa sebagain besar responden dalam kategori usia reproduksi sehat, yaitu usia 20-35 tahun sebanyak 52,1\% dan yang paling sedikit adalah usia $<20$ tahun sebanyak 1,4\%. Berdasarkan Pendidikan responden paling paling adalah Pendidikan Sarjana sebanyak $38 \%$ diikuti dengan Pendidikan
Diploma sebanyak 28,2\%. Berdasarkan karakteristik pekerjaan sebagian besar responden bekerja swasta sebanyak 42,2\%.

Dalam penelitian ini usia reproduksi sehat mendominasi usia responden. Seiring dengan bertambahnya usia seseorang maka akan terjadi perubahan perilaku dimana mereka akan sulit menerima informasi, mereka kurang aktif, mudah terserang penyakit dan cederung mengabaikan PHBS. Hal ini diungkapkan (Muhammad Tauiq, 2013) mengatakan bahwa usia muda lebih mudah menerima informasi dan lebih bersifat dinamis dibandingkan usia tua, sehingga lebih mudah menerima perubahan perilaku. Hasil penelitian ini didukung oleh penelitian yang dilakukan oleh Prihanti et al (2018) yang mengatakan usia memiliki pengaruh secara signifikan dalam mempengaruhi perilaku PHBS.

Menurut Iskriyanti (2002), umur merupakan suatu faktor yang dapat menggambarkan kematangan fisik, psikis ataupun sosial dan sekurangkurangnya berpengaruh dalam proses pembelajaran. Hal tersebut terbukti pada hasil penelitian yang didapat, bahwa semakin bertambah usia akan 
Jurnal Kesehatan Karya Husada, No 8 Vol 2 Tahun 2020

PISSN 2337649X/EISSN 2655-8874

Benny Karuniawati, Berlina Putrianti "' Gambaran Perilaku Hidup Bersih dan Sehat (PHBS) dalam Pencegahan Penularan Covid-19" (hal 112-131)

semakin mempengaruhi perilaku seseorang termasuk penerapan PHBS.

Usia reproduksi sehat cenderung lebih patuh dalam melaksanakan PHBS.

Karakteristik responden berdasarkan Pendidikan, sebagain besar Pendidikan diploma dan sarjana dengan totak prosentase $66,2 \%$. Tingkat pendidikan dapat mempengaruhi perilaku hidup bersih dan sehat, dimana semakin tinggi tingkat pendidikan maka akan mematangkan pemahaman tentang pengetahuan khususnya kesehatan lingkungan dan kesadaran menjaga kesehatan lingkungan termasuk penerapan prinsip - prinsip PHBS. Hal ini diperjelas oleh Mubarak dalam Muhammad tauiq (2013) yang mengatakan bahwa pendidikan sebagai suatu proses dalam rangkaian yang akan mempengaruhi dan menimbulkan perubahan perilaku pada diri nya, karena semakin tinggi tingkat pendidikan seseorang semakin mudah mereka menerima informasi kesehatan. Sebaliknya jika seseorang yang tingkat pendidikannya rendah, maka akan menghambat perkembangan seseorang terhadap penerimaan, informasi kesehatan dan nilai-nilai baru yang diperkenalkan.
Menurut Ritzer (2005). Pendidikan dan penghasilan merupakan sebagian unsur struktur sosial yang mempengaruhi sistem sosial. Artinya pendidikan dan penghasilan mempengaruhi perilaku. Hal itu terbukti dari hasil penelitian ini. Hasil penelitian ini menunjukkan bahwa semakin tinggi tingkat pendidikan seseorang akan semakin patuh dan taat dalam melaksanakan PHBS.

Hal ini didukung oleh hasil penelitian Kusumawati, et. al (2008) menjelaskan bahwa ada hubungan antara pendidikan dengan perilaku hidup bersih dan sehat. Hal ini juga sesuai dengan hasil penelitian Zaahara dalam Kusumawati, et. al (2008) yang juga mengemukakan bahwa status sosial ekonomi yang didalamnya termasuk pendidikan mempunyai hubungan dengan perilaku hidup bersih dan sehat. Adanya keterkaitan antara pendidikan dengan perilaku hidup bersih dan sehat mempunyai hubungan yang signifikan dengan tingkat kesehatan. Makin tinggi tingkat pendidikan semakin mudah menerima konsep hidup sehat secara mandiri, kreatif dan berkesinambungan. 
Jurnal Kesehatan Karya Husada, No 8 Vol 2 Tahun 2020

PISSN 2337649X/EISSN 2655-8874

Benny Karuniawati, Berlina Putrianti "' Gambaran Perilaku Hidup Bersih dan Sehat (PHBS) dalam Pencegahan Penularan Covid-19" (hal 112-131)

Dengan penerapan PHBS yang berkesinambungan dan tertib harapannya penularan Covid-19 dapat diminimalisir. Ketika masyarakat mau menerapkan PHBS, penularan covid19 dapat ditekan, sehingga dapat memutus rantai penyebarannya. Salah satu hal yang dapat dilakukan oleh masyarakat dalam upaya pencegahan penyebaran virus Covid-19 adalah dengan sering mencuci tangan dengan sabun, mengunakan masker, dan menjaga jarak, seperti apa yang diungkapkan oleh WHO. Penelitian ini pun menunjukkan hasil yang posistif.

Responden penelitian selalu mencuci tangan setelah memegang uang, selalu menggunakan masker ketika keluar rumah, dan selalu menjaga jarak dengan orang lain.

Aktifitas mencuci tangan setelah melakukan aktivitas diluar rumah sangat penting dilakukan mengingat selama perjalanan seseorang pasti terpapar polusi udara dan menyentuh berbagai hal. Berdasarkan penelitian yang dilakukan Rizky (menunjukkan bahwa dengan kebiasaan mencuci tangan setelah bermain mengurangi kejadian cacingan pada anak. Hal ini pun dapat disimpulkan dengan mencuci tangan setelah melakukan aktvitas juga dapat mengurangi penularan bakteri atau virus yang didapatkan dari luar rumah.

Mencuci tangan dengan sabun sebelum makan juga perlu dilakukan. Salah satu langkah untuk mencegah penyebaran virus Corona adalah dengan cuci tangan sebelum makan maupun melakukan aktivitas apapun menggunakan sabun dan air mengalir selama 20 detik. Pilih sabun maupun cairan pencuci tangan yang mengandung alkohol sebesar $60 \%$. Cara mencuci tangannya pun harus tepat agar Anda terhindar dari virus Corona, kuman dan bakteri. Hal ini sesuai dengan penelitian Umar (2008) menyatakan bahwa terdapat perilaku cuci tangan berpengaruh terhadap kejadian infeksi. si kecacingan. Tujuan cuci tangan adalah menghi-langkan kotoran dan debu secara mekanis dari per-mukaan kulit dan secara bermakna mengurangi jumlah mikroorganisme penyebab penyakit seperti virus, bakteridan parasit lainnya pada kedua tangan. Mencuci tangan dengan menggunakan air dan sabun dapat lebih efektif membersihkan kotoran dan telur 
Jurnal Kesehatan Karya Husada, No 8 Vol 2 Tahun 2020

PISSN 2337649X/EISSN 2655-8874

Benny Karuniawati, Berlina Putrianti "' Gambaran Perilaku Hidup Bersih dan Sehat (PHBS) dalam Pencegahan

Penularan Covid-19" (hal 112-131)

cacing yang menempelpada permukaan kulit, kuku dan jari-jari.

Tidak hanya kebersihan diri, kebersihan rumah juga perlu dijaga. Hal ini penting dilakukan sebagai salah satu upaya untuk mengurangi risiko penularan virus Corona, terutama bila ada penghuni rumah yang sedang menjalani isolasi mandiri. Hal ini sesuai protokol isolasi mandiri yang dikeluarkan oleh pemerintah, disebutkan bahwa salah satu hal yang harus dilakukan adalah menjaga kebersihan diri dan tempat tinggal.

Virus Corona terbukti dapat bertahan hidup selama berjam-jam bahkan berhari-hari di permukaan suatu benda. Oleh karena itu, untuk mencegah infeksi virus Corona, perlu membersihkan rumah secara menyeluruh.

Dalam masa pandemi penggunakaan masker sangat penting diperhatikan. Saat ini, menggunakan masker disarankan bagi orang yang bepergian untuk mengantisipasi penularan virus Corona. Virus ini terdapat pada percikan air liur orang yang sakit ketika ia bersin, batuk, atau bahkan saat berbicara. Penularan terjadi ketika percikan air liur terhirup orang lain yang ada di sekitar. Hal ini sesuai dengan penelitian Zamahsyahri (2013) menyatakan bahwa tindakan pemakaian masker mempunyai hubungan yang signifikan dengan gangguan fungsi paru. Seperti halnya dengan penyakit Covid 19 yang menyerang paru-paru, masker pun juga memiliki fungsi untuk mencegah penularan penyakit tersebut.

WHO menyatakan untuk mencegah penularan Covid 19 salah satunya adalah dengan menjaga jarak dengan orang lain sejauh 1 sampai 3 meter, terlebih jika ada orang yang batuk dan bersin. Hal ini sesuai dengan penelitian Karuniawati (2015) Penyakit TBC bisa menular ke orang lain, sumber penularan adalah kuman yang ada dalam dahak, cara penularan yang paling sering adalah ketika pasien TBC batuk atau bersin, sinar matahari langsung dapat membunuh bakteri, untuk mencegah penularan maka alat makan pasien harus disendirikan. Serupa dengan penularan penyakit TBC penyakit Covid 19 juga ditularkan melalui dorplet sehingga menjaga jarak merupakan hal yang 
Jurnal Kesehatan Karya Husada, No 8 Vol 2 Tahun 2020

PISSN 2337649X/EISSN 2655-8874

Benny Karuniawati, Berlina Putrianti "' Gambaran Perilaku Hidup Bersih dan Sehat (PHBS) dalam Pencegahan Penularan Covid-19" (hal 112-131)

penting dalam mencegah penyakit Covid 19.

Salah satu cara penularan virus Covid 19 adalah dengan melakukan kontak langsung atau kontak fisik dengan seseorang yang terinfeksi virus tersebut. Perkembangan kasus virus Covid 19 saat ini sudah menyerang seseorang dengan tanpa gejala. (OTG). orang yang positif Covid 19 tanpa gejala ini yang sebenarnya cukup membahayakan karena tidak ada ciri- ciri atau tanda-tanda bahwa orang tersebut positif Covid. Untuk itu, alangkah baiknya apabila menjaga kontak langsung dengan orang lain. Berjabat tangan merupakan salah satu tindakan yang sudah menjadi budaya di masyarakat indonesia. Orang indonesia akan saling berjabat tangan apabila bertemu. Hal ini merupakan salah satu peyebab penularan virus Covid 19. Berdasarkan penelitian ini, Responden sudah sangat sadar terhadap pentingnya menjaga kontak langsung dengan sesama orang lain.

Berdasarkan hasil penelitian ini, responden sebanyak $68 \%$ sudah tidak pernah melakukan jabat tangan dengan orang lain. Hal ini tentu akan menekan angka penyebaran virus Covid 19 .
Tangan merupakan salah satu bagian tubuh yang sering sekali kontak dengan benda asing yang mungkin bisa menjadi salah satu droplet virus Covid 19. Untuk itu, dengan tidak berjabat tangan dengan orang lain menjadi salah satu alternatif untuk menghindari penularan virus Covid 19.

Menjaga jarak atau menjaga kontak langsung dengan orang lain merupakan cara yang cukup efektif untuk mencegah penularan virus Covid 19. salah satu hal yang bisa dilakukan untuk mencegah penularan virus Covid 19 adalah dengan tidak melakukan aktivitas diluar rumah.Dengan tidak beraktivitas di luar rumah, seseorang dapat menekan angka penyebaran virus Covid 19. mengurang kegiatan aktivitas di luar rumah dapat menjadi salah satu cara untuk menjaga seseorang dari kontang langsung dan fisik terhadap orang yang positif virus Covid 19.

Berdasarkan hasil penelitian ini, masih terdapat beberapa responden yang selalu melakukan aktivitas di luar rumah. Hal ini tentu akan meningkatakan risiko responden tersebut terkena paparan virus Covid 19. akan tetapi, kebanyakan responden 
Jurnal Kesehatan Karya Husada, No 8 Vol 2 Tahun 2020

PISSN 2337649X/EISSN 2655-8874

Benny Karuniawati, Berlina Putrianti “" Gambaran Perilaku Hidup Bersih dan Sehat (PHBS) dalam Pencegahan Penularan Covid-19" (hal 112-131)

sudah mengurangi kegiatan di luar rumah, sehingga hal ini diharapakan bisa menekan penularan virus tersebut. Staf pengajar Fakultas Kedokteran Universitas Indonesia (FKUI)

Budiman Bela mengatakan bahwa penting untuk menjaga kualitas sirkulasi udara untuk mencegah virus corona penyebab COVID-19 bisa bertahan di udara. Hal itu disampaikannya terkait dengan informasi mengenai potensi virus penyebab COVID-19 bisa bertahan di udara atau menyebar secara aerosol. Oleh karena itu, menjaga sirkulasi udara yang baik di rumah merupakan salah satu bentuk upaya penyebaran virus Covid 19 di rumah.

Hasil penelitian ini menunjukkan bahwa responden sudah menjaga sirkulasi udara di rumah masingmasing dengan selalu membuka jendela dan ventilasi. Hal ini tentu menjadi salah satu upaya perwujudan pencegahan penyebaran virus Covid 19. Kesadaran ini tentu juga menjadi sebuah hal yang menggembirakan di tengah pandemi virus ini. Ini menunjukkan bahwa masyarakat sudah sangat sadar untuk melakukan beberapa hal dalam menanggulani penyebaran virus Covid 19.

Selain itu, hal yang dapat dilakukan untuk menjaga penyebran virus Covid 19 adalah dengan rajin membersihkan permukaan benda dengan cairan pembersih. Kebersihan lingkungan merupakan hal yang tak terpisahkan dari kehidupan manusia dan merupakan unsur yang fundamental dalam ilmu kesehatan dan pencegahan (Lastriyah, 2011). Hasil penleitian ini menunjukkan bahwa responden sering membersihkan permukaan benda dengan cairan desinfektan. Ini menunjuukkan kesadaran masyarakat sudah sangat baik dalam melkukan tindakan pencegahan penularan virus Covid 19.

Selain hal-hal yang bebrbau fisik, menjaga asupan makanan yang bersih dan sehat juga merupakan salah satu bentuk upaya untk meningkatkan kesehatan dan daya tahan tubuh. Dengan daya tahan tubuh yang sehat, virus Covid 19 tidak akan mudah menular kepada seseorang. Responden dalam penelitian ini sudah melakukan hal tersebut dengan baik. Dari hasil penelitian, sebesar $71,8 \%$ responden sudah memakan 
Jurnal Kesehatan Karya Husada, No 8 Vol 2 Tahun 2020

PISSN 2337649X/EISSN 2655-8874

Benny Karuniawati, Berlina Putrianti "'Gambaran Perilaku Hidup Bersih dan Sehat (PHBS) dalam Pencegahan Penularan Covid-19" (hal 112-131)

makanan yang sehat dan bergizi. Ini tentu menjadi sebuah tindakan yang sangat baik dalam upaya pencegahan penularan virus Covid 19.

Menurut Departemen Gizi dan Kesehatan Masyarakat FKMUI (2007:14), zat gizi merupakan bahan dasar yang menyusun bahan makanan. Zat gizi yang dikenal ada lima, yaitu karbohidrat, protein, lemak, vitamin dan mineral. Sedangkan bahan makanan atau yang sering dikenal dengan bahan pangan dikelompokkan menjadi empat kelompok, yaitu (1) bahan makanan pokok), (2) bahan makanan lauk-pauk, (3) bahan makanan sayur, dan (4) bahan makanan buah. Dengan pemenuhan gizi dalam makanan tersebut, daya tahan tubuh dan kesehatan tubuh dapat ditingkatkan, sehingga tidak akan mudah terserang pemyakit.

Merokok merupakan salah satu aktivitas yang sangat mengganggu kesehatam. Pada saat merokok, berbagai zat beracun akan terserap ke dalam tubuh. Tidak hanya bagi perokok saja, asap rokok tenyata juga sangat berbahaya bagi orang yang menghirupnya. Maka dari itu, merokok merupakan sebuak tindakan yang dapat berdampak pada kesehatan. Berdasarkan hasil penelitian, responden sudah paham betul tentang bahaya dari merokok. Hasil penelitian menunjukkan bahwa sebesar $42 \%$ responden sudah tidak pernah merokok. Angka tersebut cukup menggembirakan di tengah- tengah keiinginan masyarakat dalam melawan dan mencegah penyebaran virus Covid 19. hal itu menunjukkan bahwa masayarakat sudah semakin sadar betapa bahayanya kandungan racun yang terdapat dalam rokok dan betapa bahayanya asap rokok bagi orang lain yang menghirupnya.

Sebagai salah satu bentuk upaya pencegahan penularan virus Covid 19 adalah dengan menjaga daya tahan tubuh dan kesehatan tubuh, Salah satu cara untuk meningkatakan kesehatan dan menjaga kebugaran tubuh adalah dengan melakukan olahraga atau aktivitas fisik setiap hari. Aktivitas fisik tersebut bisa dilakukan di dalam atau di luar rumah. Agar tidak mudah bosan dan sebagai bentuk penyegaran hendaknya melakukan aktivitas di luar rumah. Apapaun bentuk aktivitas fisik di luar rumah 
Jurnal Kesehatan Karya Husada, No 8 Vol 2 Tahun 2020

PISSN 2337649X/EISSN 2655-8874

Benny Karuniawati, Berlina Putrianti "' Gambaran Perilaku Hidup Bersih dan Sehat (PHBS) dalam Pencegahan Penularan Covid-19" (hal 112-131)

merupakan salah satu kegiatan yang dapat menjaga kebugaran dan kesehatan tubuh. Akan tetapi, aktivitas di luar rumah yang dilakukan harus tetap menjaga protokol kesehatan.

Hasil penelitian menunjukkan bahwa aktifitas fisik memberikan keuntungan yang besar untuk menurunkan risiko penyakit jantung. Orang yang kurang melakukan aktifitas fisik berisiko dua kali lebih besar terkena penyakit jantung bila dibandingkan orang yang tidak aktif. Aktifitas fisik juga membantu mencegah penyakit stroke dan memperbaiki faktor resiko cardiovascular disease (CVD) seperti tekanan darah tinggi dan tinggi kolesterol (Welis, 2013).

Berdasarkan hasil penelitian yang dilakukan, responden ternyata belum sadar terhadap pentingnya manfaat berolahraga. Itu terbukti dengan hasil penelitian yang diperoleh bahwa responden hanya kadang-kadang saja melakukan olahraga selama minimal 30 menit. Untuk itu, tentu perlu ditingkatkan lagi kesdaran masyarakat tentang pentingnya berolahraga dalam upaya menjaga kesehatan dan khusunya dalam menjaga penularan virus Covid 19.
Mencuci segala sesuatu dengan sabun merupakan salah satu cara yang cukup efektif untuk menghilangkan kuman, tak terkecuali buah dan sayuran. Buah dan sayur yang dibeli dari supermarket atau pasar beum tentu terbebas dari virus dan kuman. Untuk itu penting mencuci sayur dan buah tersebut sebelum dikonsumsi. Kesadaran akan hal tersebut nampaknya sudah sangat dipahami oleh masyarakat. Berdasarkan hasil peneitian yang diperoleh, responden yang mencuci buah dan sayur sebesar 95\%. Ini berarti bahwa masyarakat sudah sangat sadar betapa pentingnya mencuci buah dan sayur untuk menghilangkan virus dan kuman yang terdapat dalam buah dan sayur tersebut, sehingga buah dan sayur tersebut aman untuk dikonsumsi. Uang merupakan salah satu benda yang sering menjadi perantara kontak langsung dengan sesama. Uang dapat menjadi salah satu droplet yang dapat menyebarkan virus Covid 19. Oleh karena itu, hendaknya setelah memegang uang untuk rajin mencuci tangan dengan menggunakan sabun. Hasil penelitian menunjukkan bahwa sebesar $49 \%$ responden mencuci tangan setelah memegang uang. Hal ini 
Jurnal Kesehatan Karya Husada, No 8 Vol 2 Tahun 2020

PISSN 2337649X/EISSN 2655-8874

Benny Karuniawati, Berlina Putrianti "' Gambaran Perilaku Hidup Bersih dan Sehat (PHBS) dalam Pencegahan Penularan Covid-19" (hal 112-131)

berarti bahwa masayarakat sudah sadar betapa pentingnya mencuci tangan setelah memegang benda tak terkecuali uang untuk mencegah penularan dan penyebaran virus Covid 19.

Hidup sehat memang merupakan dambaan bagi setiap orang, tetapi kesadaran untuk menjalankan hidup sehat belum sepenuhnya terlaksana. Pada masa pandemi virus Covid 19, masyarakat dituntut untuk dapat membiasakan hidup sehat bagi masing-masing individu ataupun di lingkungan keluarga. Membiasakan hidu sehat di lingkungan keluarga memang bukan perkara yang mudah, butuh ketaatan dan kedisiplinan yang kuat agar anggota keluarga menerapakan perilaku hidup sehat. Hasil penelitian ini menunjukkan selama masa pandemi virus Covid 19 saat ini, perilaku hidup ehat di keluarga sangat meningkat.

Responden sebesar $77,5 \%$ selalu membiasakan berperilaku hidup sehat. Dengan berperilaku hidup sehat, harapannya anggota keluarga tidak mudah terserang virus dan kuman yang menjadi sumber penyakit. Hasil penelitian ini juga menunjukkan bahwa kesadaran masyarakat tentang pentingnya berperilaku hidup sehat sangat tinggi.

Cairan merupakan salah satu kebutuhan tubuh yang harus tercukupi. Kebutuhn cairan dalam tubuh manusia memang beragam. Akan tetapi, kebutuhan cairan tubuh seseorang idealnya adalah sebanyak 2 liter atau 8 gelas air putih. Semakin terpenuhi kebutuhan cairan tubuh seseorang tentu akan semakin baik metabolisme dalam dirinya. Pada masa pandemi virus Covid 19 saat ini, tentu setiap orang hendaknya dapat mencukupi kebutuhan cairan tubuhnya minimal 2 liter per hari agar tidak dehidrasi. Hal ini nampaknya sudah menjadi kesadaran oleh setiap orang.

Berdasarkan penelitian yang dilakukan, responden dalam penelitian ini yang selalu mencukupi kebutuhan cairan tubuhnya minimal sebesar 2 liter per hari adalah 78,9\%. Ini dapat diartikan bahwa hampirsetiap orang mencukupi kebutuhan cairan tubuhnya, sehingga tidak mengalami dehidrasi. Apabila cairan tubuh terpenuhi, seseorang akan tidak mudah diserang penyakit. Ketika seseorang memiliki imunitas yang baik, virus Covid 19 tidak mudah menyerang. 
Jurnal Kesehatan Karya Husada, No 8 Vol 2 Tahun 2020

PISSN 2337649X/EISSN 2655-8874

Benny Karuniawati, Berlina Putrianti "' Gambaran Perilaku Hidup Bersih dan Sehat (PHBS) dalam Pencegahan Penularan Covid-19" (hal 112-131)

Selama beberapa bulan belakangan ini, pemerintah mengeluarkan beberapa kebijakan terkait pandemi virus covid yang terjadi di Indonesia dan di seluuh dunia. Pemerintah melakukan PSBB di semua bidang, termasuk salah satunya adalah transpotasi antarderah dan antarnegara. Beberapa waktu belakangan ini, pemerintah daerah di Indonesia melarang warga dari dalam dan luar daerah untuk berpergian. Hal ini tentu merupakan salah satu langkah antisipasi yang dilakukan guna menekan angka penyebaran virus

Covid 19.

Dengan tidak adanya kunjungan orang dari luar daerah, pemerintah daerah akan lebih mudah memanatu penyebaran virus tersebut. Ada masyarakat yang paham dan mau melaksanakan aturan tersebut, tetapi ada pula masyarakat yang secara sembunyi- sembunyi melanggar aturan tersebut terutama pada saat mudik lebaran. Akan tetapi, secara keseluruhan masih banyak masyarakat yang patuh dan taat terhadap aturan tersebut karena mereka tahu pentingnya kebijakan tersebut dibuat untuk memutus rantai penyebaran virus Covid 19.

Hal ini terlihat dari hasil penelitian bahwa sebanyak $84,5 \%$ responden tidak melakukan perjalanan keluar kota selama masa pandemi ini. Ini dapat diartikan bahwa masyarakat sadar betul pentingnya untuk menaati aturan tersebut guna menekan angka penyebaran virus Covid 19. hal ini sepele, tetapi cukup efektif untuk menekan penyebaran virus tersebut.

\section{SIMPULAN DAN SARAN}

Penelitian ini menyimpulkan bahwa masyarakat saat ini sudah sangat sadar dengan PHBS. Semakin bertambah usia akan semakin paham dan mengerti tentang PHBS, serta menerapkan PHBS dengan baik. Selain itu, tingkat pendidikan ternyata juga berpengaruh terhadap penerapan PHBS. Semakin tinggi tingkat pendidikan akan semakin paham terhadap PHBS. Dengan penerapan PHBS yang baik, diharapakan dapat mencegah penyebaran virus Covid-19. 
Jurnal Kesehatan Karya Husada, No 8 Vol 2 Tahun 2020

PISSN 2337649X/EISSN 2655-8874

Benny Karuniawati, Berlina Putrianti "'Gambaran Perilaku Hidup Bersih dan Sehat (PHBS) dalam Pencegahan

Penularan Covid-19" (hal 112-131)

DAFTAR PUSTAKA

Kementerian Kesehatan Republik Indonesia, 2012. Profil Data Kesehatan Indonesia Tahun 2011.

Holshue, M. L., DeBolt, C., Lindquist, S., Lofy, K. H., Wiesman, J., Bruce, H., ... Pillai, S. K. (2020). First case of 2019 novel coronavirus in the United States. New England Journal of Medicine, Vol. 382, pp. 929-936.

https://doi.org/10.1056/NEJMoa2 $\underline{001191}$

Muhammad Tauiq, M. N. \& S. R. (2013). Gambaran Prilaku Hidup Bersih dan Sehat (PHBS) Masyarakat Di Kelurahan Parangloe Kecamatan Tamalanrea Kota Makassar. 112. Retrieved from repository.unhas.ac.id

Prihanti, G. S., A., L. D., R, H., I., A. I., P., H. S., P., G. R., \& F., S. (2018). Faktor-Faktor Yang Mempengaruhi Tingkat Perilaku Hidup Bersih Dan Sehat Pada Tatanan Rumah Tangga Di Wilayah Kerja Puskesmas Poned X. Saintika Medika, 14(1), 7

14.https://doi.org/10.22219/sm.vo 114.smu mm1.6644

Wikipedia. (2010). Advice for the Public Sector (pp. 1-16). pp. 1-16. Retrieved from http://en.wikipedia.org/wiki/Wiki p edia:GLAM

Zou, L., Ruan, F., Huang, M., Liang, L., Huang, H., Hong, Z., ... Wu, J. (2020). SARS-CoV-2 viral load in upper respiratory specimens of infected patients. New England Journal of Medicine, Vol. 382, pp.1177-1179.

https://doi.org/10.1056/NEJMc20 01737

Pneumonia of unknown cause China: disease outbreak news. Geneva: World Health Organization, January5, 2020 (https://www.who. int/csr/don/05january-2020- pneumonia-ofunkown-cause- china/en/. opens in new tab).

Proverawati, Atikah. 2012.Perilaku Hidup Bersih Dan Sehat (PHBS). Yogyakarta: Nuha Medika.

Ritzer, George, Douglas J. Goodman.2007. Teori Sosiologi Modern. Jakarta: Kencana.

Iskriyanti, Hari. 2002. Hubungan Karakteristik, Pengetahuan dan Sikap Ibu Rumah Tangga Tentang PHBS Dengan Praktek Kesehatan Keluarga dan Kesehatan Lingkungan di Kelurahan Rejowinangun Kecamatan Kota Gede Kota Yogyakarta Agustus 2002. Semarang :UNDIP.

Kusumawati, Y., Astuti, D., Ambarwati.2008. Hubungan antara Pendidikan dan Pengetahuan Kepala Keluarga tentang Kesehatan Lingkungan dengan Perilaku Hidup Bersih dan Sehat

\begin{tabular}{ccr} 
(PHBS). Jurnal & \multicolumn{2}{r}{ Kesehatan } \\
Masyarakat. & Vol. & 1, \\
No.1.Juni.2008 & &
\end{tabular}


Jurnal Kesehatan Karya Husada, No 8 Vol 2 Tahun 2020

PISSN 2337649X/EISSN 2655-8874

Benny Karuniawati, Berlina Putrianti "'Gambaran Perilaku Hidup Bersih dan Sehat (PHBS) dalam Pencegahan Penularan Covid-19" (hal 112-131)

Welis, Wilda \& Sazeli Rifki, Muhamad. (2013) .Gizi untuk Aktifitas Fisik dan Kebugaran, ISBN : 978-602-1650-028.https://www.liputan6.com/healt $\mathrm{h} / \mathrm{read} / 4$

301725/sirkulasi-udara-yang- baikcegah-virus-corona-covid-19bertahan-di-udara. 